\title{
Imaging Diagnostic and Therapeutic Targets: Human Epidermal Growth Factor Receptor 2
}

\author{
Geraldine Gebhart ${ }^{1}$, Patrick Flamen ${ }^{1}$, Elisabeth G.E. De Vries ${ }^{2}$, Komal Jhaveri*3, and Zena Wimana*1 \\ ${ }^{1}$ Department of Nuclear Medicine, Institut Jules Bordet-Université Libre de Bruxelles (ULB), Brussels, Belgium; ${ }^{2}$ Department of \\ Medical Oncology, University Medical Center Groningen, University of Groningen, Groningen, The Netherlands; and ${ }^{3}$ Breast \\ Medicine Service, Memorial Sloan Kettering Cancer Center, New York, New York
}

Since the approval of trastuzumab, a humanized monoclonal antibody against the extracellular domain of human epidermal growth factor receptor 2 (HER2), 3 other HER2-targeting agents have gained regulatory approval: lapatinib, pertuzumab, and trastuzumab-emtansine. These agents have revolutionized the management of HER2-positive breast cancer, highlighting the concept that targeted therapies are successful when patients exhibit tumor-selective expression of a molecular target-in this case, HER2. However, response prediction and innate or acquired resistance remain serious concerns. Predictive biomarkers of a response-which could help in the selection of patients who might benefit from a selected targeted therapy-are currently lacking. Molecular imaging with anti-HER2 probes allows the noninvasive, whole-body assessment of HER2 tumor burden and has the potential to improve patient selection, optimize the dose and schedule, and rationalize assessment of the response to anti-HER2 therapies. Furthermore, unlike biopsy-based HER2 assessment, this approach can reveal inter- or intratumoral heterogeneity as well as variations in HER2 expression over time. This review summarizes the available literature and the current status of molecular imaging as a tool for the assessment of HER2 (target) expression or the prediction of an early treatment response in early and advanced HER2-positive breast cancer.

Key Words: molecular imaging; breast oncology; PET/CT; SPECT/ CT; HER2 imaging; human epidermal growth factor receptor

J Nucl Med 2016; 57:81S-88S

DOI: 10.2967/jnumed.115.157941

\section{H}

uman epidermal growth factor receptor 2 (HER2) is overexpressed in several cancers, including breast, gastric, ovary, prostate, bladder, and lung cancers, and is a proven therapeutic target in the first 2 tumor types $(1,2)$. In breast cancer (BC), in particular, HER2 overexpression is found in $15 \%-25 \%$ of patients and is associated with a clinically aggressive course. Successful targeting of HER2 with a range of anti-HER2 drugs has resulted in markedly improved patient outcomes in both advanced and early disease settings (3).

Received Jul. 9, 2015; revision accepted Oct. 9, 2015.

For correspondence or reprints contact: Geraldine Gebhart, Department of Nuclear Medicine, Institut Jules Bordet, 121 Boulevard de Waterloo, 1000 Brussels, Belgium.

E-mail: geraldine.gebhart@bordet.be

${ }^{*}$ Contributed equally to this work.

COPYRIGHT (c) 2016 by the Society of Nuclear Medicine and Molecular Imaging, Inc.
However, the presence of a target (in this case, HER2) does not always guarantee benefit from matched targeted therapies because downstream signaling resistance or escape can occur. In HER2overexpressing $\mathrm{BC}$, it has been estimated that about $50 \%$ of patients with metastases do not benefit from anti-HER2 therapies (4), and not a single biomarker for identifying nonresponding patients has yet been validated (5).

Furthermore, there is increasing evidence of temporal and spatial heterogeneity in BC HER2 overexpression. Patients with negative test results at diagnosis can have positive test results later in the disease course and vice versa, a fact that explains why biopsy of metastatic disease is a strong recommendation of many clinical treatment guidelines (6). Heterogeneity in biomarker expression at metastatic sites is only beginning to be recognized, with growing appreciation for molecular imaging.

This article focuses on HER2-positive BC and provides a comprehensive overview of the present and future roles of molecular imaging in improving target mapping, predicting benefit from chemotherapy with or without anti-HER2 drugs, and selecting patients for the targeted delivery of potent cytotoxic agents or therapeutic isotopes.

\section{IMAGING OF HER2 (TARGET) EXPRESSION}

In clinical practice, HER2 status is determined by immunohistochemistry (IHC) (usually with an antibody recognizing the intracellular domain of the receptor (7)) or fluorescence in situ hybridization (FISH), mostly from the primary tumor and sometimes from a metastatic lesion. HER 2 positivity is defined as an IHC score of $3+$ or an IHC score of $2+$ with a FISH score of greater than or equal to $2.0(8)$.

Bearing in mind the heterogeneity of HER 2 expression and the resulting issues with macro- and microsampling of tumor samples, whole-body HER2 imaging could complement current standard approaches. Depending on the desired HER2 imaging techniqueSPECT or PET-various isotopes can be used, with the latter modality offering images with higher resolution or sensitivity and allowing quantification.

Imaging can be performed with various targeting molecules, such as antibodies, peptides, small-molecule ligands, and aptamers. A fulllength, high-molecular-weight monoclonal antibody (mAb) offers slow blood hepatobiliary clearance. In contrast, its bioengineered derived fragments $\left[\mathrm{Fab}\right.$ fragments, $\left.\mathrm{F}\left(\mathrm{ab}^{\prime}\right)_{2}\right]$ and variants $(\mathrm{scFv}$, diabodies, and minibodies) and nontraditional protein scaffolds (Affibody molecules, Nanobodies, and anticalins) result in faster pharmacokinetics with similar affinity and specificity (9). These low-molecular-weight probes can be radiolabeled with isotopes-such as ${ }^{68} \mathrm{Ga},{ }^{18} \mathrm{~F},{ }^{64} \mathrm{Cu}$, and ${ }^{76} \mathrm{Br}$ for PET imaging - that have a short halflife, allowing imaging on the day of injection with a low radiation burden. In contrast, when mAbs are radiolabeled with isotopes that 
have a longer half-life — such as ${ }^{89} \mathrm{Zr},{ }^{124} \mathrm{I}$, and ${ }^{86} \mathrm{Y}$ for PET imaging and ${ }^{111}$ In for SPECT imaging — images can be retrieved up to several days after tracer injection, allowing optimal uptake in tumor tissue.

\section{Preclinical Setting}

Since the introduction of trastuzumab (a humanized $\mathrm{mAb}$ against HER2) for the treatment of HER2-positive BC more than a decade ago (4), trastuzumab-based HER2 imaging has received increasing attention, with some modalities reaching a successful transition from the laboratory to the clinic.

${ }^{111} \mathrm{In}-,{ }^{86} \mathrm{Y}$-, and ${ }^{225}$ Ac-radiolabeled trastuzumab (10-12) was introduced first; ${ }^{89} \mathrm{Zr}$-trastuzumab (13) was introduced a few years later in human tumor-bearing mice. Specific tumor uptake in HER2 tumor-bearing mice was confirmed with higher resolution and better quantification on ${ }^{89} \mathrm{Zr}$-trastuzumab PET images. In addition to high stability and maintenance of affinity, this tracer had the immunoreactivity and internalization properties of trastuzumab, despite the radiolabeling modifications. Furthermore, it was recently demonstrated (14) that trastuzumab-based tracers, such as ${ }^{89} \mathrm{Zr}$-trastuzumab, can reveal more than the mere expression of HER2; they can reveal its accessibility. Steric hindrance of mucin MUC4, masking the trastuzumab-binding epitope on HER2, negatively affected ${ }^{89} \mathrm{Zr}$-trastuzumab tumor uptake. This effect could be counteracted by supplementation with a mucolytic agent, such as $\mathrm{N}$-acetylcysteine, in patient-derived HER2- and MUC4-overexpressing tumors (JIMT1).

An anti-HER2 mAb introduced later-pertuzumab-was also radiolabeled with ${ }^{111} \mathrm{In}$ or ${ }^{89} \mathrm{Zr}$ and was used to successfully image HER2-positive tumor xenografts $(15,16)$.

In addition to mAbs, several reports have demonstrated the usefulness of HER2 imaging with Affibody-based tracers. Interestingly, in a study directly comparing a ${ }^{124} \mathrm{I}$-trastuzumab mAb with Affibody ${ }^{124}$ I-ZHER2:342, the Affibody showed even higher tumor-to-organ ratios than the $\mathrm{mAb}$ because of rapid clearance of radioactivity from blood and normal organs (17).

Several anti-HER2 Affibody molecules have also been labeled with ${ }^{68} \mathrm{Ga},{ }^{18} \mathrm{~F},{ }^{64} \mathrm{Cu}$, and ${ }^{11} \mathrm{C}$ for PET and with ${ }^{99 \mathrm{~m}} \mathrm{Tc}$ and ${ }^{111} \mathrm{In}$ for SPECT (18-21). Affibody ABY-002 radiolabeled with ${ }^{111} \mathrm{In}$ for SPECT as well as with ${ }^{68} \mathrm{Ga}$ for PET was shown to specifically target HER2-expressing xenografts in vivo with both isotopes, but the pharmacokinetic profile for ${ }^{68} \mathrm{Ga}$-radiolabeled ABY-002 was favored (20). Both tracers were investigated further in BC patients (22); the findings were in agreement with the preclinical data.

Furthermore, to guarantee maintenance of the targeting abilities of low-molecular-weight Affibody molecules, Wållberg et al. proposed a Sel-tagging technique enabling site-specific ${ }^{11} \mathrm{C}$ radiolabeling of anti-HER2 Affibody ZHER2:342, resulting in a molecule with lower kidney retention and an overall absorbed dose comparable to that of ${ }^{68}$ Ga-ZHER2:342 (21).

HER2 imaging has also been investigated with even smaller probes, namely Nanobodies (23,24). Many anti-HER2 Nanobodies for the noninvasive imaging of HER2 expression have been proposed (23). Studies with Nanobodies radiolabeled with ${ }^{99 \mathrm{~m}} \mathrm{Tc}$ (2Rs15dHis6) in mice bearing HER2-positive tumors revealed fast blood clearance, low accumulation in nontarget organs (except the kidneys, which are responsible for tracer clearance), and high concomitant tumor-to-blood and tumor-to-muscle ratios at $1 \mathrm{~h}$ after injection (24). PET imaging of HER 2 expression with ${ }^{68} \mathrm{Ga}$-radiolabeled Nanobodies is currently being evaluated by the same group of researchers (Fig. 1) (25).

In addition to the aforementioned probes, oligonucleotides, RNA, and DNA aptamers were recently introduced. A modified

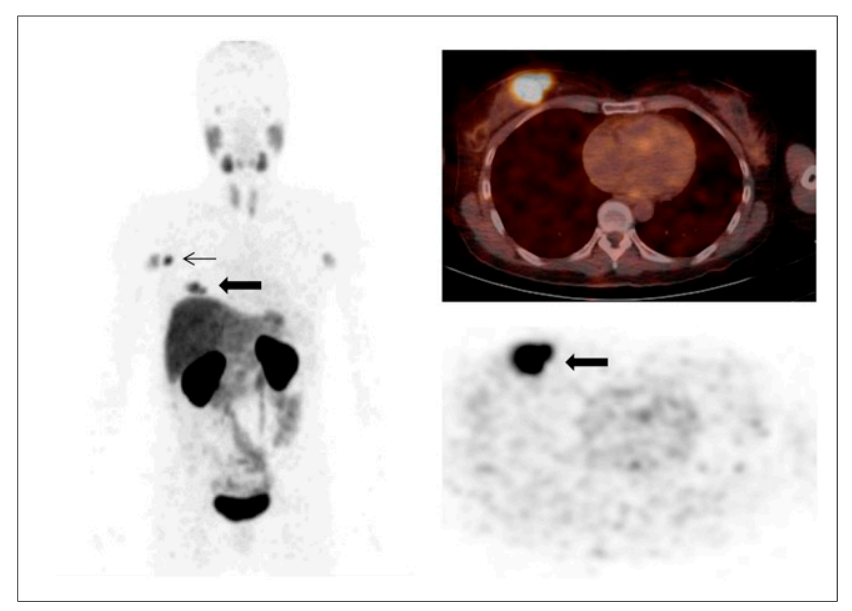

FIGURE 1. Uptake of ${ }^{68} \mathrm{Ga}$-HER2-Nanobody in primary breast carcinoma (thick arrow) and invaded lymph node (thin arrow) with high HER2 expression. (Left) Maximum-intensity-projection PET image. (Top right) $\mathrm{PET} / \mathrm{CT}$ fusion image. (Bottom right) Corresponding PET image. (Courtesy of Marleen Keyaerts, UZ Brussel, Brussels, Belgium.)

RNA aptamer with HER2-specific targeting was labeled with ${ }^{99 \mathrm{~m} T c}$ and allowed SPECT imaging of HER2 expression $(26,27)$. Another group used ${ }^{64} \mathrm{Cu}$-WT4340 for PET imaging of HER2 messenger RNA and also demonstrated its successful use for evaluating the therapeutic efficacy of doxorubicin therapy in immunocompromised mice carrying human HER2-positive BC xenografts (28). These new types of radiotracers have so far been investigated only in preclinical models.

Furthermore, various groups have also investigated the use of HER2 imaging for the evaluation of molecular responses to anti-HER2 therapy (heat shock protein 90 [HSP90] and trastuzumab) in vivo in human tumor xenografts with ${ }^{68} \mathrm{Ga}$-labeled $\mathrm{F}\left(\mathrm{ab}^{\prime}\right)_{2}$-trastuzumab (29), ${ }^{89} \mathrm{Zr}$-trastuzumab (30), and ${ }^{18} \mathrm{~F}-\mathrm{N}$-[2-(4-fluorobenzamido) ethyl]maleimide-ZHER2:342 PET/CT (31) and ${ }^{111}$ In-pertuzumab SPECT/CT (16). All of these modalities allowed the sensitive detection of HER2 downregulation.

\section{Clinical Setting}

Table 1 summarizes the results of 7 clinical studies of HER2 imaging in $\mathrm{BC}$ patients.

In 2000, a pilot study with 10 HER2-positive metastatic BC patients treated with trastuzumab concluded that ${ }^{111}$ In-trastuzumab immunoscintigraphy allowed diagnostic predictions with respect to therapeutic efficacy and cardiotoxicity (32). Others investigating this issue in HER2-positive advanced BC patients before treatment with trastuzumab and paclitaxel (33) reported different results. Indeed, of the 15 patients, only 1 showed myocardial uptake not translating into the development of heart failure.

Nonetheless, HER2-positive tumors were imaged, albeit with a low detection rate, probably because of the poor resolution of SPECT. Imaging quality was remarkably improved with the introduction of ${ }^{89} \mathrm{Zr}$-trastuzumab, allowing PET imaging (13). The best time for the assessment of tracer uptake in metastatic lesions was determined to be $4-5 \mathrm{~d}$ after tracer administration. Brain metastases, among other metastatic sites, were also successfully imaged. The study also highlighted the importance of the mass of administered protein, concluding that in trastuzumab-naive patients, a higher mass of (nonradiolabeled) trastuzumab $(50 \mathrm{mg})$ enabled better distribution of the tracer into the metastatic lesions. 
TABLE 1

Molecular Imaging Studies Seeking to Confirm HER2 Overexpression in Early and Advanced HER2-Positive Breast Cancer

\begin{tabular}{|c|c|c|c|c|c|}
\hline Type of probe & $\begin{array}{l}\text { PET or SPECT } \\
\text { probe and dose }\end{array}$ & Patient population & $\begin{array}{l}\text { Optimal timing } \\
\text { for imaging }\end{array}$ & Findings & Study \\
\hline \multirow[t]{5}{*}{$\begin{array}{l}\text { Intact } \\
\text { monoclonal } \\
\text { antibodies }\end{array}$} & $\begin{array}{l}111 \text { In-trastuzumab } \\
\text { (185 MBq) with } \\
\text { variable amount } \\
\text { of trastuzumab }\end{array}$ & $\begin{array}{l}\text { Advanced disease } \\
\qquad(n=10)\end{array}$ & Not mentioned & $\begin{array}{l}\text { Ability to predict } \\
\text { cardiotoxicity } \\
\text { and response } \\
\text { to trastuzumab }\end{array}$ & $\begin{array}{l}\text { Behr et al. (32) } \\
\quad(2000)\end{array}$ \\
\hline & $\begin{array}{l}{ }^{111} \text { In-trastuzumab } \\
(100-150 \mathrm{MBq}) \\
\text { after first } \\
\text { therapeutic dose } \\
\text { of trastuzumab }\end{array}$ & $\begin{array}{l}\text { Advanced disease } \\
\quad(n=15)\end{array}$ & $\begin{array}{l}\text { Up to } 7 \mathrm{~d} \text { after } \\
\text { injection }\end{array}$ & $\begin{array}{l}\text { Low tumor } \\
\text { detection rate; } \\
\text { no ability to } \\
\text { predict } \\
\text { trastuzumab- } \\
\text { induced } \\
\text { cardiotoxicity }\end{array}$ & $\begin{array}{l}\text { Perik et al. (33) } \\
\quad(2006)\end{array}$ \\
\hline & $\begin{array}{l}{ }^{89} \mathrm{Zr} \text {-trastuzumab } \\
\text { (37 MBq + either } \\
10 \text { or } 50 \mathrm{mg} \text { of } \\
\text { trastuzumab) }\end{array}$ & $\begin{array}{l}\text { Advanced disease } \\
\text { ( } n=14) \text {, on or off } \\
\text { trastuzumab } \\
\text { therapy }\end{array}$ & $\begin{array}{l}\text { Day } 4 \text { or } 5 \text { after } \\
\text { injection }\end{array}$ & $\begin{array}{l}\text { Excellent tumor } \\
\text { uptake; } \\
\text { visualization } \\
\text { of metastasis in } \\
\text { liver, bone, } \\
\text { lungs, and } \\
\text { brain; } 50 \text { mg } \\
\text { of trastuzumab } \\
\text { needed if } \\
\text { patients were } \\
\text { off trastuzumab }\end{array}$ & $\begin{array}{l}\text { Dijkers et al. (13) } \\
\text { (2010) }\end{array}$ \\
\hline & $\begin{array}{l}{ }^{64} \text { Cu-trastuzumab } \\
\text { (130 MBq); no } \\
\text { unlabeled } \\
\text { trastuzumab }\end{array}$ & $\begin{array}{c}\text { Early and advanced } \\
\text { disease }(n=6)\end{array}$ & $48 \mathrm{~h}$ after injection & $\begin{array}{l}\text { No "cold" } \\
\text { trastuzumab } \\
\text { used; } \\
\text { suboptimal } \\
\text { visualization } \\
\text { of liver lesions; } \\
\text { primary tumors } \\
\text { and brain } \\
\text { metastasis seen }\end{array}$ & $\begin{array}{l}\text { Tamura et al. (34) } \\
\text { (2013) }\end{array}$ \\
\hline & $\begin{array}{l}{ }^{64} \mathrm{Cu} \text {-trastuzumab } \\
\text { (364-512 MBq); } \\
5 \mathrm{mg} \text { of } \\
\text { trastuzumab } \\
\text { preceded by } \\
\text { trastuzumab } \\
\text { infusion ( } 45 \mathrm{mg} \text { ) }\end{array}$ & $\begin{array}{l}\text { Advanced disease } \\
\text { ( } n=8) \text {, off } \\
\text { trastuzumab } \\
\text { therapy for } \\
\geq 4 \text { mo }\end{array}$ & $48 \mathrm{~h}$ after injection & $\begin{array}{l}\text { Mapping of } \\
\text { lesions close to } \\
\text { that obtained by } \\
{ }^{18} \mathrm{~F}-\mathrm{FDG} \text { PET; } \\
\text { some lesions } \\
\text { seen only } \\
\text { on }{ }^{64} \mathrm{Cu}- \\
\text { trastuzumab } \\
\text { PET; } 45 \text { mg } \\
\text { of cold } \\
\text { trastuzumab } \\
\text { needed }\end{array}$ & $\begin{array}{l}\text { Mortimer et al. (35) } \\
\text { (2014) }\end{array}$ \\
\hline \multirow[t]{2}{*}{$\begin{array}{l}\text { Affibody } \\
\text { molecules }\end{array}$} & $\begin{array}{l}{ }^{111} \text { In- or }{ }^{68} \mathrm{Ga}- \\
\text { labeled ABY-002 } \\
(80-90 \mathrm{mg}, \text { with } \\
\text { activity ranging } \\
\text { from } 110 \text { to } 267 \\
\mathrm{MBq})\end{array}$ & $\begin{array}{l}\text { Advanced disease } \\
(n=3) \text {, on or off } \\
\text { trastuzumab } \\
\text { therapy }\end{array}$ & $3 \mathrm{~h}$ after injection & $\begin{array}{l}\text { High rate of } \\
\text { detection of } \\
\text { known lesion on } \\
\text { 18F-FDG PET; } \\
\text { high level of } \\
\text { liver or kidney } \\
\text { uptake is } \\
\text { problematic }\end{array}$ & $\begin{array}{l}\text { Baum et al. (22) } \\
\quad(2010)\end{array}$ \\
\hline & $\begin{array}{l}{ }^{111} \mathrm{In}-\mathrm{ABY}-025 \text { (100 } \\
\text { mg, with mean } \\
\text { activity of } 142.6 \\
\text { MBq; range, } \\
\text { 131-154 MBq) }\end{array}$ & $\begin{array}{l}\text { Advanced disease } \\
\text { ( } n=7) \text { with } 5 \\
\text { HER2-positive and } \\
2 \text { HER2-negative } \\
\text { tumors; some on } \\
\text { trastuzumab } \\
\text { therapy }\end{array}$ & $24 \mathrm{~h}$ after injection & $\begin{array}{l}\text { Visualization of } \\
\text { HER2-positive } \\
\text { metastases, } \\
\text { including those } \\
\text { in liver or brain }\end{array}$ & $\begin{array}{l}\text { Sörensen et al. (36) } \\
\text { (2014) }\end{array}$ \\
\hline
\end{tabular}


In addition, trastuzumab was also labeled with ${ }^{64} \mathrm{Cu}$ in studies of both early and advanced HER2-positive BC $(34,35)$. In both studies, the best time for imaging was $48 \mathrm{~h}$ after tracer injection. However, the results were different; the coinjection of $45 \mathrm{mg}$ of trastuzumab enabled better visualization of liver metastases (35), whereas the results obtained with the administration of only the radiotracer were suboptimal because of a higher liver background (34). Interestingly, both studies compared ${ }^{64} \mathrm{Cu}$-trastuzumab PET/CT with ${ }^{18}$ F-FDG PET/CT, with a maximum of $13 \mathrm{~d}$ in between, and showed that some lesions could be detected only with ${ }^{64} \mathrm{Cu}$-trastuzumab PET/CT.

Apart from HER2-directed antibodies, 2 different Affibody molecules, ABY-002 (22) and ABY-025 (36,37), were labeled with ${ }^{68} \mathrm{Ga}$ or ${ }^{111} \mathrm{In}$ and injected into patients with advanced BC. In all of the studies, the radiolabeled Affibody molecules allowed imaging of HER2-positive lesions and even brain metastases (36). In the most recent study, increasing tracer uptake over time allowed discrimination between HER2-positive and HER2-negative lesions on the basis of radiotracer uptake and as confirmed by IHC (37). One issue was that because of the high background uptake of the radiolabeled Affibody molecules in the liver, the HER2 status of lesions in this organ could not be properly assessed.

Furthermore, successive HER2 imaging for different therapies was also studied. In one study, HER2 downregulation in the presence of an HSP90 inhibitor could be monitored through a decrease in ${ }^{89} \mathrm{Zr}$-trastuzumab uptake and was correlated with a response by RECIST 1.0 (38). In another study by the same group, trastuzumab combined with paclitaxel treatment led to a $20 \%$ decrease in ${ }^{111}$ In-trastuzumab tumor uptake. Interestingly, although tumor uptake decreased, HER2 imaging was still achievable, suggesting that sufficient HER2 is constantly available at the tumor cell membrane to bind trastuzumab (39).

Regardless of the aforementioned findings, it is critical to demonstrate that assessing HER2 with molecular imaging in advanced BC has clinical utility. Three prospective clinical trials have been designed to address this important question: 1 study at Institut Jules Bordet (NCT01420146) and 2 studies at the University Medical Center Groningen (NCT01832051 and NCT01957332) (Fig. 2).

\section{NONSPECIFIC IMAGING (WITH ${ }^{18}$ F-FDG PET/CT) TO PREDICT PATHOLOGIC RESPONSE TO SYSTEMIC THERAPIES FOR EARLY HER2-POSITIVE BC}

The use of ${ }^{18} \mathrm{~F}-\mathrm{FDG}$ tumor uptake as a biomarker for predicting a pathologic response to neoadjuvant treatment has been explored in the preclinical and clinical settings, with conflicting results.

\section{Preclinical Setting}

Ex vivo results demonstrated that significant changes in ${ }^{18} \mathrm{~F}-\mathrm{FDG}$ incorporation with trastuzumab therapy could be assessed (40). Furthermore, in vivo changes in ${ }^{18} \mathrm{~F}-\mathrm{FDG}$ tumor uptake after therapy accurately differentiated responding and nonresponding human BC xenografts in athymic mice treated with trastuzumab (41). In contrast, in 2 other studies, ${ }^{18}$ F-FDG PET could not show an effect of trastuzumab treatment or of an HSP90 inhibitor in mice implanted with HER2-positive human BC tumors $(40,42)$. Interestingly, Fleming et al. reported conflicting results in the same study and postulated that Akt inhibition and the glucose transport rate interfered with ${ }^{18} \mathrm{~F}-\mathrm{FDG}$ incorporation and compromised the ability of ${ }^{18} \mathrm{~F}-\mathrm{FDG}$ PET to measure treatment responses (43).

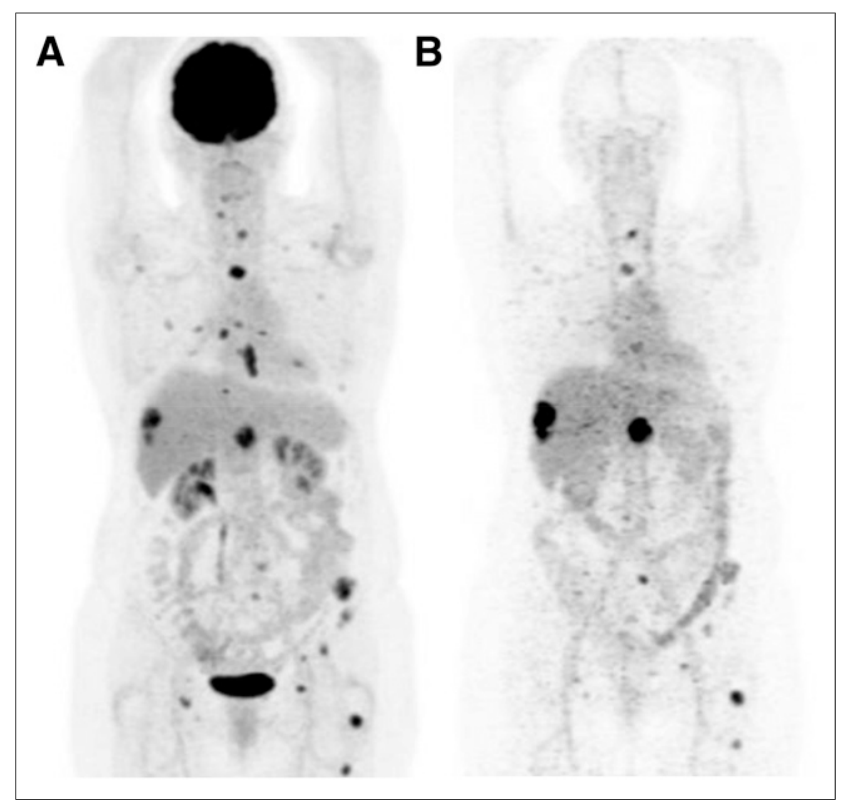

FIGURE 2. Representative molecular PET images of patient with HER2-positive breast cancer. Liver and bone metastases were visualized by ${ }^{18} \mathrm{~F}-\mathrm{FDG}(\mathrm{A})$ and HER2 (B) imaging with ${ }^{89} \mathrm{Zr}$-trastuzumab, the latter illustrating high uptake in liver lesions and heterogeneous uptake in bone lesions.

\section{Clinical Setting}

In women receiving systemic treatment for HER2-positive $\mathrm{BC}$ before surgery, the use of early ${ }^{18}$ F-FDG PET as a predictor of a pathologic complete response (pCR), a surrogate marker of diseasefree survival and overall survival, was explored (44). Table 2 summarizes these studies, which were heterogeneous in terms of types of systemic therapies, timing of ${ }^{18} \mathrm{~F}-\mathrm{FDG}$ PET, definition of $\mathrm{pCR}$, and pCR rates. All studies but one (45) showed a correlation between early ${ }^{18} \mathrm{~F}$-FDG PET/CT results and the probability of reaching a pCR. In the "negative" study, the cohort was small (only 25 patients), ${ }^{18} \mathrm{~F}-\mathrm{FDG}$ PET/CT was performed 6-8 wk after the start of treatment with the chemotherapy-trastuzumab combination, and the axillary nodes were not evaluated.

Among the "positive" studies, 2 studies opted for the evaluation of a metabolic response after 2 cycles of up-front anthracyclinebased chemotherapy given as part of a sequential anthracyclinetaxane-trastuzumab regimen $(46,47)$. The other studies scheduled early ${ }^{18} \mathrm{~F}$-FDG PET/CT up front after 1 or 2 cycles of a taxaneand trastuzumab-based combination (48-50).

Furthermore, the multicenter phase 3 Neoadjuvant Lapatinib or Trastuzumab Treatment Optimization (Neo-ALTTO) study was the only one that explored the predictive value of ${ }^{18} \mathrm{~F}-\mathrm{FDG}$ PET/CT for dual anti-HER2 therapy given exclusively during a 6-wk "biologic window" and followed by the addition of paclitaxel (51).

The ${ }^{18} \mathrm{~F}-\mathrm{FDG}$ PET/CT parameters found to correlate most strongly with a pCR were either the absolute residual $\mathrm{SUV}_{\max }$ on early ${ }^{18}$ F-FDG PET/CT $(46,49)$ or the change in the $\mathrm{SUV}_{\max }$ threshold $(47,48,50,51)$.

Of note, a multivariate analysis to assess the independent predictive value of early ${ }^{18} \mathrm{~F}$-FDG PET/CT was performed in only 3 studies; the predictive value was confirmed in 2 studies $(48,49)$. However, in the study conducted by our group (51), the hormone receptor status of the tumor was the most powerful predictor of a pCR. Furthermore, 
TABLE 2

${ }^{18}$ F-FDG PET/CT Studies Performed During Neoadjuvant Systemic Therapy to Predict pCR in HER2-Positive Breast Cancer

\begin{tabular}{|c|c|c|c|c|c|c|}
\hline $\begin{array}{c}\text { Type of systemic } \\
\text { therapy }\end{array}$ & Type of study & $\begin{array}{l}\text { Timing of } \\
\text { early }{ }^{18} \mathrm{~F}- \\
\text { FDG PET }\end{array}$ & $\begin{array}{l}\text { pCR rate (\%) in breast } \\
\text { and lymph nodes }\end{array}$ & $\begin{array}{l}\text { Best predictor of } \\
\text { pCR }\end{array}$ & $\begin{array}{l}\text { Confirmation in } \\
\text { multivariate } \\
\text { analysis }\end{array}$ & Study \\
\hline $\begin{array}{l}\text { Epirubicin- } \\
\text { cyclophosphamide } \\
\text { (4 cycles and then } \\
\text { docetaxel- } \\
\text { trastuzumab) }\end{array}$ & $\begin{array}{l}\text { Single center } \\
\quad(n=30)\end{array}$ & After 2 cycles & 53 & $\begin{array}{l}\text { Absolute } \\
\text { residual } \\
\text { SUV }_{\text {max }} \text { at } \\
\text { PET } 2 \text { of } \leq 3 \\
\text { (breast or } \\
\text { axilla) (AUC, } \\
0.91 \text { ) }\end{array}$ & Not done & $\begin{array}{l}\text { Groheux et al. } \\
\text { (46) (2013) }\end{array}$ \\
\hline $\begin{array}{l}\text { Anthracycline } \\
\text { (followed by taxane) } \\
\text { or taxane }+ \\
\text { trastuzumab; } \\
\text { 6-8 cycles }\end{array}$ & $\begin{array}{l}\text { Single center } \\
\quad(n=14)\end{array}$ & After 2 cycles & 29 & $\begin{array}{l}50 \% \text { change in } \\
\text { SUV }_{\text {max }} \\
\text { threshold with } \\
100 \% \text { NPV }\end{array}$ & Not done & $\begin{array}{l}\text { Zucchini et al. } \\
\text { (47) (2012) }\end{array}$ \\
\hline $\begin{array}{l}\text { Trastuzumab, lapatinib, } \\
\text { or their combination } \\
\text { (later combined with } \\
\text { paclitaxel) }\end{array}$ & $\begin{array}{l}\text { Multicenter } \\
\qquad(n=66)\end{array}$ & $\begin{array}{l}\text { After } 2 \text { and } 6 \\
\text { wk of } \\
\text { biologic } \\
\text { therapy }\end{array}$ & 35 & $\begin{array}{l}\text { Metabolic R } \\
\text { (EORTC } \\
\text { criteria) had } \\
\text { doubling of } \\
\text { pCR rate }\end{array}$ & $\begin{array}{l}\text { No (hormone } \\
\text { receptor } \\
\text { status was } \\
\text { strongest } \\
\text { predictor) }\end{array}$ & $\begin{array}{l}\text { Gebhart et al. } \\
\text { (51) (2013) }\end{array}$ \\
\hline $\begin{array}{l}\text { Docetaxel }+ \\
\text { trastuzumab }\end{array}$ & $\begin{array}{l}\text { Single center } \\
\quad(n=57)\end{array}$ & After 1 cycle & 44 & $\begin{array}{l}\text { SUV }_{\text {max }} \text { at PET } 2 \\
\text { of }<2.1 \text {, with } \\
\text { required } \\
\text { SUV }_{\max } \text { at } \\
\text { PET } 1 \text { of } \geq 3.7\end{array}$ & Yes & $\begin{array}{l}\text { Humbert et al. } \\
\text { (49) (2014) }\end{array}$ \\
\hline $\begin{array}{l}\text { Paclitaxel + } \\
\text { carboplatin }+ \\
\text { trastuzumab }\end{array}$ & $\begin{array}{l}\text { Single center } \\
\quad(n=25)\end{array}$ & After 6-8 wk & $60^{*}$ & $\begin{array}{l}{ }^{18} \text { F-FDG PET } \\
\text { results not } \\
\text { correlated } \\
\text { with pCR }\end{array}$ & Not done & $\begin{array}{l}\text { Koolen et al. } \\
(45)(2013)\end{array}$ \\
\hline $\begin{array}{l}\text { Trastuzumab + } \\
\text { docetaxel, with or } \\
\text { without carboplatin }\end{array}$ & $\begin{array}{l}\text { Single center } \\
\qquad(n=37)\end{array}$ & After 1 cycle & 38 & $\begin{array}{l}\geq 75 \% \text { change in } \\
\text { SUV }{ }_{\text {max }} ; \text { pCR } \\
\text { accuracy, } \\
76 \%\end{array}$ & Yes & $\begin{array}{l}\text { Humbert et al. } \\
\text { (48) (2012) }\end{array}$ \\
\hline $\begin{array}{l}\text { Trastuzumab }+ \\
\text { docetaxel in case } \\
\text { of poor metabolic } \\
\text { response, with or } \\
\text { without bevacizumab }\end{array}$ & $\begin{array}{l}\text { Multicenter } \\
\qquad(n=142)\end{array}$ & After 2 cycles & $\begin{array}{l}54 \text { in PET R; } 24 \text { in } \\
\text { PET NR; } 44 \text { in } \\
\text { PET NR receiving } \\
\text { bevacizumab }\end{array}$ & $\begin{array}{l}\geq 70 \% \text { change in } \\
\text { SUV }_{\max }\end{array}$ & Not done & $\begin{array}{l}\text { Coudert et al. } \\
\text { (50) (2014) }\end{array}$ \\
\hline
\end{tabular}

${ }^{\star}$ Evaluated in breast only.

AUC = area under the curve; NPV = negative predictive value; $\mathrm{R}=$ responders; EORTC = European Organization for Research and Treatment of Cancer; NR = nonresponders.

the study by Coudert et al. is of particular interest because it investigated the concept of a "response-adapted strategy" - escalating therapy with bevacizumab in patients showing a poor metabolic response on ${ }^{18} \mathrm{~F}$-FDG PET/CT while receiving neoadjuvant trastuzumab and docetaxel (50). The authors demonstrated that the pCR rate was higher when bevacizumab was added than when the neoadjuvant therapy was unchanged.

Although the aforementioned studies reported encouraging results, the clinical utility of performing an early metabolic assessment during neoadjuvant therapy is far from being validated. The clinical utility of any biomarker assessment requires a demonstration that using the biomarker for treatment decision making improves clinical outcomes. Of note, such a demonstration is the last step of a challenging process of biomarker validation, which also comprises the demonstration of analytic and clinical validity (52).
Studies larger than the elegant study by Coudert et al. (50) will have to be performed and will involve the collaboration of several centers. Critical will be the use of common standardized PET imaging procedures like those developed by Boellaard et al. (53) for the validation of imaging biomarkers. Such multicenter prospective trials will need to explore and validate all or some of the different imagederived parameters extracted from sequential ${ }^{18} \mathrm{~F}-\mathrm{FDG}$ PET and thought to be correlated with a pCR. Although a change in the $\mathrm{SUV}_{\text {max }}$, a change in the $\mathrm{SUV}_{\text {peak }}$, and the absolute residual $\mathrm{SUV}_{\text {max }}$ are the parameters most frequently used in studies of HER2-positive BC-mainly because of their reproducibility-other parameters, such as tumor lesion glycolysis, have also been assessed. A retrospective study (54) compared variations in the change in the $\mathrm{SUV}_{\max }$, the metabolically active tumor volume, and tumor lesion glycolysis at baseline and after 2 cycles of neoadjuvant chemotherapy (4 cycles 
of epirubicin plus cyclophosphamide followed by 4 cycles of docetaxel [plus trastuzumab in cases of HER2-positive BC]). The authors concluded that the change in tumor lesion glycolysis was the most accurate parameter for the prediction of a pCR, mainly in estrogen receptor-positive, HER2-negative tumors.

\section{HER2 IMAGING TO PREDICT RESPONSE TO NEW ANTI-HER2 THERAPIES FOR ADVANCED HER2-POSITIVE BC}

The first large prospective clinical study aimed at exploring HER2 imaging as a clinically useful predictive biomarker in advanced HER2-positive BC is the ZEPHIR study. This multicenter study of advanced HER2-positive BC (NCT01565200), which is a collaborative effort between Belgian and Dutch centers, aims to prospectively examine the role of pretreatment ${ }^{89} \mathrm{Zr}$-trastuzumab PET/CT (HER2 scan) and early ${ }^{18} \mathrm{~F}-\mathrm{FDG}$ PET/ CT (performed just before the second cycle of the antibody-drug conjugate [T-DM1]) in identifying lesions that will not respond to T-DM1. Preliminary data on the patient-based predictive abilities of these 2 PET scans, used alone or in combination, have been presented (55) and are promising. A high negative predictive value $(100 \%)$ was found for ${ }^{89} \mathrm{Zr}$-trastuzumab PET results categorized as "negative" at baseline and an absence of a metabolic response on ${ }^{18}$ F-FDG PET/CT after one cycle of T-DM1. Furthermore, this study demonstrated that so-called advanced HER2-positive BC was a highly heterogeneous disease, with approximately one-third of patients showing the absence of HER2-specific targeting in all or most metastatic lesions.

Nonetheless, the determination of "negative" lesions must be made with great caution. False-negative results obtained for HER2 lesions by imaging have been described in patients with a high tumor load (56). This finding was seen in patients with ${ }^{89} \mathrm{Zr}$ trastuzumab uptake predominantly in the liver on the HER2 scan and subsequent rapid clearance of the tracer from the circulation. The reiteration of the HER2 scan in the presence of trastuzumab therapy resulted in improved pharmacokinetics and enabled better uptake of the tracer in bone lesions. The ZEPHIR study has been extended, with a requirement for biopsies for "HER2-negative" lesions, with the hope of confirming the initial encouraging results.

\section{HER2-TARGETED THERAPY WITH RADIOACTIVE ANTI-HER2 PROBES}

As previously mentioned, anti-HER2 probes have been successfully radiolabeled with various isotopes for diagnostic purposeswith SPECT and PET — as well as for targeted therapies.

Radioimmunotherapy (RIT) has been investigated predominantly and extensively with trastuzumab and therapeutic radionuclides, such as $\beta$-emitters ${ }^{177} \mathrm{Lu}(57-60),{ }^{90} \mathrm{Y}(60,61)$, and ${ }^{188} \mathrm{Re}$ $(62,63)$; Auger electron emitter ${ }^{111}$ In (64); and even $\alpha$-emitter actinium (12). All showed therapeutic efficacy in HER2-expressing xenografts. In addition, a combination of RIT and radiosensitizing chemotherapy was shown to potentiate the therapeutic effect of ${ }^{212} \mathrm{~Pb}$-radiolabeled trastuzumab, resulting in prolonged median survival in HER2-positive xenograft models (65). RIT with ${ }^{90} \mathrm{Y}-$ trastuzumab was even found to be applicable to BC expressing small amounts of HER2 (61). The results obtained with other candidates for RIT, such as the smaller Affibody molecules (66) and Nanobodies $\left({ }^{177} \mathrm{Lu}(67)\right.$ or $\left.{ }^{90} \mathrm{Y}(68)\right)$, have been encouraging. In addition, a first-in-human study assessing the safety of intraperitoneal $\alpha$-RIT with ${ }^{212} \mathrm{~Pb}$-TCMC-trastuzumab was presented recently. The latter approach showed an acceptable degree of early toxicity and absence of late toxicity (69).

\section{CONCLUSION AND PERSPECTIVES}

HER2 is an important target in the management of BC. Therefore, the assessment of HER2 is an essential step in the diagnostic workup and the selection of optimal treatments in both early-stage and metastatic settings. However, the heterogeneity of the disease, particularly in the metastatic setting, and the limited number of metastases that can be easily accessed for a biopsy remain issues of concern for the clinically available tests (IHC and FISH) with which HER2 status is determined.

Several anti-HER2 probes developed for both SPECT and PET have been proposed since the early 2000s as noninvasive approaches for assessing whole-body HER2 expression patterns, and some probes have successfully reached the clinical setting (Table 1). Small molecules-such as antibody fragments, Affibody molecules, and Nanobodies — offer the advantages of rapid uptake and clearance, uptake in tumors, and a low radiation burden for patients, thus enabling both early ( $1 \mathrm{~h}$ after administration) and serial HER2 imaging. In contrast, mAbs, with their slow clearance, allow for optimal imaging after several days at the cost of a higher radiation burden. Nonetheless, mAbs not only offer the advantage of identifying the presence of HER2 expression but also provide insight on $\mathrm{mAb}$-target interactions, such as target availability or accessibility and complex internalization. These abilities are important for predicting responses to mAb-based treatments because accessibility is dependent on the size of the probe as well as the presence of the binding epitope on the target $(14,70)$.

At present, predicting which type of HER2 tracer will be preferred in the clinical setting is difficult. We propose that the actual indication for HER2 imaging will dictate the choice of the imaging modality. For instance, low-molecular-weight probes could offer an alternative to IHC or FISH for diagnostic purposes or for the prediction of responses to treatment with small molecules (e.g., lapatinib, radiolabeled Nanobodies). In contrast, mAbs might be preferred when the intention is to treat with mAb-based therapies (e.g., trastuzumab, T-DM1, pertuzumab, radiolabeled $\mathrm{mAbs}$ ). With regard to the recently introduced messenger RNA aptamers, further studies are needed, but these agents might be used to monitor treatment responses.

Of note is the fact that in preclinical models as well as in humans, the amount of protein or peptide influences the in vivo distribution pattern of the tracer $(37,56,71)$. This fact was demonstrated in various studies in which increasing the nonradioactive probe content increased the contrast until a particular "threshold," beyond which the contrast decreased, was reached. Therefore, the optimal amount of a probe, rather than the maximum obtainable specific activity, should be considered.

${ }^{18}$ F-FDG PET/CT has been used extensively in the neoadjuvant setting as an integrated biomarker to predict a pCR. Although the results have been encouraging, the next step is to establish its value as an integral biomarker that allows treatment deescalation or escalation on the basis of an early metabolic response/nonresponse or a poor response, respectively, as noted on ${ }^{18} \mathrm{~F}$-FDG PET early after treatment initiation. Given the plethora of anti-HER2 agents that are currently clinically available and the lack of predictive tissue biomarkers beyond HER2, there is certainly a pressing need to demonstrate the clinical utility of noninvasive HER2 imaging or ${ }^{18}$ F-FDG PET/CT in advanced disease (e.g., helping to select a subset of patients who might most benefit or not benefit from a particular anti-HER2 therapy). 
Molecular imaging has great potential to become a valuable tool in this new era of "personalized and precision medicine." Important steps in adapting a new "image and treat" strategy in HER2-positive $\mathrm{BC}$ have already been accomplished. With additional prospective clinical studies and validation, molecular imaging in HER2-positive BC could allow patient-tailored dosage adaptation, with early cessation of futile (and expensive) therapies and deescalation of "aggressive" treatment, ultimately resulting in cost savings, lower morbidity, and improved patient outcomes.

\section{DISCLOSURE}

No potential conflict of interest relevant to this article was reported.

\section{REFERENCES}

1. Chmielecki J, Ross JS, Wang K, et al. Oncogenic alterations in ERBB2/HER2 represent potential therapeutic targets across tumors from diverse anatomic sites of origin. Oncologist. 2015;20:7-12.

2. Singh JC, Jhaveri K, Esteva FJ. HER2-positive advanced breast cancer: optimizing patient outcomes and opportunities for drug development. Br J Cancer. 2014;111: 1888-1898.

3. Hudis CA. Trastuzumab: mechanism of action and use in clinical practice. $N$ Engl J Med. 2007;357:39-51.

4. Slamon DJ, Leyland-Jones B, Shak S, et al. Use of chemotherapy plus a monoclonal antibody against HER2 for metastatic breast cancer that overexpresses HER2. N Engl J Med. 2001;344:783-792.

5. Nuciforo PG, Aura C, Holmes E, et al. Benefit to neoadjuvant anti-human epidermal growth factor receptor 2 (HER2)-targeted therapies in HER2-positive primary breast cancer is independent of phosphatase and tensin homolog deleted from chromosome 10 (PTEN) status. Ann Oncol. 2015;26:1494-1500.

6. Aurilio G, Disalvatore D, Pruneri G, et al. A meta-analysis of oestrogen receptor, progesterone receptor and human epidermal growth factor receptor 2 discordance between primary breast cancer and metastases. Eur J Cancer. 2014;50:277-289.

7. Schrohl AS, Pedersen HC, Jensen SS, Nielsen SL, Brunner N. Human epidermal growth factor receptor 2 (HER2) immunoreactivity: specificity of three pharmacodiagnostic antibodies. Histopathology. 2011;59:975-983.

8. Wolff AC, Hammond ME, Hicks DG, et al. Recommendations for human epidermal growth factor receptor 2 testing in breast cancer: American Society of Clinical Oncology/College of American Pathologists clinical practice guideline update. J Clin Oncol. 2013;31:3997-4013.

9. Capala J, Bouchelouche K. Molecular imaging of HER2-positive breast cancer: a step toward an individualized "image and treat" strategy. Curr Opin Oncol. 2010;22:559566.

10. Lub-de Hooge MN, Kosterink JG, Perik PJ, et al. Preclinical characterisation of ${ }^{111}$ In-DTPA-trastuzumab. Br J Pharmacol. 2004;143:99-106.

11. Garmestani K, Milenic DE, Plascjak PS, Brechbiel MW. A new and convenient method for purification of ${ }^{86} \mathrm{Y}$ with a $\mathrm{Sr}$ (II) selective resin and comparison of biodistribution of ${ }^{86} \mathrm{Y}$ and ${ }^{111}$ In labeled Herceptin. Nucl Med Biol. 2002;29:599606.

12. Borchardt PE, Yuan RR, Miederer M, McDevitt MR, Scheinberg DA. Targeted actinium-225 in vivo generators for therapy of ovarian cancer. Cancer Res. 2003;63:5084-5090.

13. Dijkers EC, Oude Munnink TH, Kosterink JG, et al. Biodistribution of ${ }^{89} \mathrm{Zr}$ trastuzumab and PET imaging of HER2-positive lesions in patients with metastatic breast cancer. Clin Pharmacol Ther. 2010;87:586-592.

14. Wimana Z, Gebhart G, Guiot T, et al. Mucolytic agents can enhance HER2 receptor accessibility for $\left[{ }^{89} \mathrm{Zr}\right]$ trastuzumab, improving HER2 imaging in a mucin-overexpressing breast cancer xenograft mouse model. Mol Imaging Biol. 2015;17:697-703.

15. Marquez BV, Ikotun OF, Wright B, Zheleznyak A, Richard P, Lapi SE. PET imaging of ${ }^{89} \mathrm{Zr}$-labeled pertuzumab in HER2-positive breast cancer xenografts [abstract]. Cancer Res. 2014;74:109.

16. McLarty K, Cornelissen B, Cai Z, et al. Micro-SPECT/CT with ${ }^{111}$ In-DTPApertuzumab sensitively detects trastuzumab-mediated HER2 downregulation and tumor response in athymic mice bearing MDA-MB-361 human breast cancer xenografts. J Nucl Med. 2009;50:1340-1348.

17. Orlova A, Wallberg H, Stone-Elander S, Tolmachev V. On the selection of a tracer for PET imaging of HER2-expressing tumors: direct comparison of a ${ }^{124} \mathrm{I}$ labeled affibody molecule and trastuzumab in a murine xenograft model. $\mathrm{J} \mathrm{Nucl}$ Med. 2009;50:417-425.
18. Cheng Z, De Jesus OP, Kramer DJ, et al. ${ }^{64} \mathrm{Cu}$-labeled Affibody molecules for imaging of HER2 expressing tumors. Mol Imaging Biol. 2010;12:316-324.

19. Kiesewetter DO, Kramer-Marek G, Ma Y, Capala J. Radiolabeling of HER2 specific Affibody molecule with F-18. J Fluor Chem. 2008;129:799-805.

20. Tolmachev V, Velikyan I, Sandstrom M, Orlova AA. HER2-binding Affibody molecule labelled with ${ }^{68} \mathrm{Ga}$ for PET imaging: direct in vivo comparison with the ${ }^{111}$ In-labelled analogue. Eur J Nucl Med Mol Imaging. 2010;37:1356-1367.

21. Wållberg H, Grafström J, Cheng $\mathrm{Q}$, et al. HER2-positive tumors imaged within 1 hour using a site-specifically ${ }^{11} \mathrm{C}$-labeled Sel-tagged Affibody molecule. $J$ Nucl Med. 2012;53:1446-1453.

22. Baum RP, Prasad V, Muller D, et al. Molecular imaging of HER2-expressing malignant tumors in breast cancer patients using synthetic ${ }^{111} \mathrm{In}$ - or ${ }^{68} \mathrm{Ga}$-labeled Affibody molecules. J Nucl Med. 2010;51:892-897.

23. Vaneycken I, Devoogdt N, Van Gassen N, et al. Preclinical screening of antiHER2 Nanobodies for molecular imaging of breast cancer. FASEB J. 2011;25: 2433-2446.

24. Xavier C, Vaneycken I, D'Huyvetter M, et al. Synthesis, preclinical validation, dosimetry, and toxicity of ${ }^{68} \mathrm{Ga}$-NOTA-anti-HER2 Nanobodies for iPET imaging of HER2 receptor expression in cancer. J Nucl Med. 2013;54:776-784.

25. Keyaerts M, Xavier C, Heemskerk J, et al. Phase I study of ${ }^{68}$ Ga-HER2Nanobody for PET/CT assessment of HER2-expression in breast carcinoma. J Nucl Med. October 8, 2015 [Epub ahead of print].

26. Varmira K, Hosseinimehr SJ, Noaparast Z, Abedi SMA. HER2-targeted RNA aptamer molecule labeled with ${ }^{99 \mathrm{~m}} \mathrm{Tc}$ for single-photon imaging in malignant tumors. Nucl Med Biol. 2013;40:980-986.

27. Varmira K, Hosseinimehr SJ, Noaparast Z, Abedi SM. An improved radiolabelled RNA aptamer molecule for HER2 imaging in cancers. $J$ Drug Target. 2014;22:116-122.

28. Paudyal B, Zhang K, Chen CP, et al. Determining efficacy of breast cancer therapy by PET imaging of HER2 mRNA. Nucl Med Biol. 2013;40:994-999.

29. Smith-Jones PM, Solit D, Afroze F, Rosen N, Larson SM. Early tumor response to Hsp90 therapy using HER2 PET: comparison with ${ }^{18}$ F-FDG PET. J Nucl Med. 2006;47:793-796.

30. Oude Munnink TH, Korte MA, Nagengast WB, et al. ${ }^{89} \mathrm{Zr}$-trastuzumab PET visualises HER2 downregulation by the HSP90 inhibitor NVP-AUY922 in a human tumour xenograft. Eur J Cancer. 2010;46:678-684.

31. Kramer-Marek G, Gijsen M, Kiesewetter DO, et al. Potential of PET to predict the response to trastuzumab treatment in an ErbB2-positive human xenograft tumor model. J Nucl Med. 2012;53:629-637.

32. Behr T, Behe M, Angerstein C, et al. Does pretherapeutic immunoscintigraphy allow for diagnostic predictions with respect to the toxicity and therapeutic efficacy of cold immunotherapy with trastuzumab (Herceptin) [abstract]? J Nucl Med. 2000;41(suppl):73P.

33. Perik PJ, Lub-De Hooge MN, Gietema JA, et al. Indium-111-labeled trastuzumab scintigraphy in patients with human epidermal growth factor receptor 2positive metastatic breast cancer. J Clin Oncol. 2006;24:2276-2282.

34. Tamura K, Kurihara H, Yonemori K, et al. ${ }^{64} \mathrm{Cu}$-DOTA-trastuzumab PET imaging in patients with HER2-positive breast cancer. J Nucl Med. 2013;54:18691875 .

35. Mortimer JE, Bading JR, Colcher DM, et al. Functional imaging of human epidermal growth factor receptor 2-positive metastatic breast cancer using ${ }^{64} \mathrm{Cu}$-DOTA-trastuzumab PET. J Nucl Med. 2014;55:23-29.

36. Sörensen J, Sandberg D, Sandstrom M, et al. First-in-human molecular imaging of HER2 expression in breast cancer metastases using the ${ }^{111}$ In-ABY-025 Affibody molecule. J Nucl Med. 2014;55:730-735.

37. Sörensen J, Velikyan I, Wennborg A, et al. Accuracy of $\left[{ }^{68} \mathrm{Ga}\right]$ ABY-025 PET/CT for determination of HER2 expression in metastatic breast cancer [abstract]. $J$ Nucl Med. 2015;56(suppl):50P.

38. Gaykema SB, Schroder CP, Vitfell-Rasmussen J, et al. ${ }^{89} \mathrm{Zr}$-trastuzumab and ${ }^{89} \mathrm{Zr}$-bevacizumab PET to evaluate the effect of the HSP90 inhibitor NVPAUY922 in metastatic breast cancer patients. Clin Cancer Res. 2014;20:39453954.

39. Gaykema SB, de Jong JR, Perik PJ, et al. ${ }^{111}$ In-trastuzumab scintigraphy in HER2-positive metastatic breast cancer patients remains feasible during trastuzumab treatment. Mol Imaging. 2014;13(July).

40. Smith TA, Appleyard MV, Sharp S, Fleming IN, Murray K, Thompson AM. Response to trastuzumab by HER2 expressing breast tumour xenografts is accompanied by decreased hexokinase II, glut1 and $\left[{ }^{18} \mathrm{~F}\right]$-FDG incorporation and changes in ${ }^{31} \mathrm{P}-\mathrm{NMR}$-detectable phosphomonoesters. Cancer Chemother Pharmacol. 2013;71:473-480.

41. McLarty K, Fasih A, Scollard DA, et al. ${ }^{18}$ F-FDG small-animal PET/CT differentiates trastuzumab-responsive from unresponsive human breast cancer xenografts in athymic mice. J Nucl Med. 2009;50:1848-1856. 
42. Shah C, Miller TW, Wyatt SK, et al. Imaging biomarkers predict response to anti-HER2 (ErbB2) therapy in preclinical models of breast cancer. Clin Cancer Res. 2009;15:4712-4721.

43. Fleming IN, Andriu A, Smith TA. Early changes in $\left[{ }^{18} \mathrm{~F}\right] \mathrm{FDG}$ incorporation by breast cancer cells treated with trastuzumab in normoxic conditions: role of the Akt-pathway, glucose transport and HIF-1alpha. Breast Cancer Res Treat. 2014;144:241-248.

44. Cortazar P, Zhang L, Untch M, et al. Pathological complete response and longterm clinical benefit in breast cancer: the CTNeoBC pooled analysis. Lancet. 2014;384:164-172.

45. Koolen BB, Pengel KE, Wesseling J, et al. FDG PET/CT during neoadjuvant chemotherapy may predict response in ER-positive/HER2-negative and triple negative, but not in HER2-positive breast cancer. Breast. 2013;22:691-697.

46. Groheux D, Giacchetti S, Hatt M, et al. HER2-overexpressing breast cancer: FDG uptake after two cycles of chemotherapy predicts the outcome of neoadjuvant treatment. Br J Cancer. 2013;109:1157-1164.

47. Zucchini G, Quercia S, Zamagni C, et al. Potential utility of early metabolic response by ${ }^{18} \mathrm{~F}$-2-fluoro-2-deoxy-D-glucose-positron emission tomography/ computed tomography in a selected group of breast cancer patients receiving preoperative chemotherapy. Eur J Cancer. 2013;49:1539-1545.

48. Humbert O, Berriolo-Riedinger A, Riedinger JM, et al. Changes in ${ }^{18} \mathrm{~F}-\mathrm{FDG}$ tumor metabolism after a first course of neoadjuvant chemotherapy in breast cancer: influence of tumor subtypes. Ann Oncol. 2012;23:2572-2577.

49. Humbert O, Cochet A, Riedinger JM, et al. HER2-positive breast cancer: ${ }^{18} \mathrm{~F}-$ FDG PET for early prediction of response to trastuzumab plus taxane-based neoadjuvant chemotherapy. Eur J Nucl Med Mol Imaging. 2014;41:1525-1533.

50. Coudert B, Pierga JY, Mouret-Reynier MA, et al. Use of $\left[{ }^{18} \mathrm{~F}\right]$-FDG PET to predict response to neoadjuvant trastuzumab and docetaxel in patients with HER2-positive breast cancer, and addition of bevacizumab to neoadjuvant trastuzumab and docetaxel in $\left[{ }^{18} \mathrm{~F}\right]-\mathrm{FDG}$ PET-predicted non-responders (AVATAXHER): an open-label, randomised phase 2 trial. Lancet Oncol. 2014; 15:1493-1502.

51. Gebhart G, Gámez C, Holmes E, et al. ${ }^{18}$ F-FDG PET/CT for early prediction of response to neoadjuvant lapatinib, trastuzumab, and their combination in HER2positive breast cancer: results from Neo-ALTTO. J Nucl Med. 2013;54:1862-1868.

52. Mankoff DA, Pryma DA, Clark AS. Molecular imaging biomarkers for oncology clinical trials. J Nucl Med. 2014;55:525-528.

53. Boellaard R, Delgado-Bolton R, Oyen WJ, et al. FDG PET/CT: EANM procedure guidelines for tumour imaging: version 2.0. Eur J Nucl Med Mol Imaging. 2015;42:328-354.

54. Hatt M, Groheux D, Martineau A, et al. Comparison between ${ }^{18}$ F-FDG PET image-derived indices for early prediction of response to neoadjuvant chemotherapy in breast cancer. $J$ Nucl Med. 2013;54:341-349.

55. Gebhart G, Lamberts LE, Garcia C, et al. PET/CT with ${ }^{89} \mathrm{Zr}$-trastuzumab and ${ }^{18} \mathrm{~F}$ FDG to individualize treatment with trastuzumab emtansine (T-DM1) in metastatic HER2-positive breast cancer (mBC) [abstract]. J Clin Oncol. 2014;32(5 suppl):11001.

56. Oude Munnink TH, Dijkers EC, Netters SJ, et al. Trastuzumab pharmacokinetics influenced by extent human epidermal growth factor receptor 2-positive tumor load. J Clin Oncol. 2010;28:e355-e356.
57. Rasaneh S, Rajabi H, Babaei MH, Daha FJ. ${ }^{177}$ Lu labeling of Herceptin and preclinical validation as a new radiopharmaceutical for radioimmunotherapy of breast cancer. Nucl Med Biol. 2010;37:949-955.

58. Rasaneh S, Rajabi H, Babaei MH, Daha FJ, Salouti M. Radiolabeling of trastuzumab with ${ }^{177} \mathrm{Lu}$ via DOTA, a new radiopharmaceutical for radioimmunotherapy of breast cancer. Nucl Med Biol. 2009;36:363-369.

59. Ray GL, Baidoo KE, Keller LM, Albert PS, Brechbiel MW, Milenic DE. Preclinical assessment of Lu-labeled trastuzumab targeting HER2 for treatment and management of cancer patients with disseminated intraperitoneal disease. Pharmaceuticals (Basel). 2011;5:1-15.

60. Beckford Vera DR, Eigner S, Eigner Henke K, Leyva Montana R, Melichar F, Beran M. ${ }^{177} \mathrm{Lu} /{ }^{90} \mathrm{Y}$ intermediate-affinity monoclonal antibodies targeting EGFR and HER2/c-neu: preparation and preclinical evaluation. Recent Results Cancer Res. 2013;194:301-317.

61. Crow DM, Williams L, Colcher D, Wong JY, Raubitschek A, Shively JE. Combined radioimmunotherapy and chemotherapy of breast tumors with Y-90-labeled anti-Her2 and anti-CEA antibodies with Taxol. Bioconjug Chem. 2005;16:11171125 .

62. Chen KT, Lee TW, Lo JM. In vivo examination of ${ }^{188} \operatorname{Re}(\mathrm{I})$-tricarbonyl-labeled trastuzumab to target HER2-overexpressing breast cancer. Nucl Med Biol. 2009;36:355361.

63. Luo TY, Cheng PC, Chiang PF, Chuang TW, Yeh CH, Lin WJ. ${ }^{188}$ Re-HYNICtrastuzumab enhances the effect of apoptosis induced by trastuzumab in HER2overexpressing breast cancer cells. Ann Nucl Med. 2015;29:52-62.

64. Costantini DL, McLarty K, Lee H, Done SJ, Vallis KA, Reilly RM. Antitumor effects and normal-tissue toxicity of ${ }^{111} \mathrm{In}$-nuclear localization sequencetrastuzumab in athymic mice bearing HER-positive human breast cancer xenografts. J Nucl Med. 2010;51:1084-1091.

65. Milenic DE, Garmestani K, Brady ED, et al. Potentiation of high-LET radiation by gemcitabine: targeting HER2 with trastuzumab to treat disseminated peritoneal disease. Clin Cancer Res. 2007;13:1926-1935.

66. Tolmachev V, Orlova A, Pehrson R, et al. Radionuclide therapy of HER2positive microxenografts using a ${ }^{177} \mathrm{Lu}$-labeled HER2-specific Affibody molecule. Cancer Res. 2007;67:2773-2782.

67. D'Huyvetter M, Vincke C, Xavier C, et al. Targeted radionuclide therapy with a ${ }^{177}$ Lu-labeled anti-HER2 Nanobody. Theranostics. 2014;4:708-720.

68. Adams GP, Shaller CC, Dadachova E, et al. A single treatment of yttrium-90labeled CHX-A"'-C6.5 diabody inhibits the growth of established human tumor xenografts in immunodeficient mice. Cancer Res. 2004;64:6200-6206.

69. Meredith R, Torgue J, Bunch P, et al. Safety of first-in-human intraperitoneal $\alpha$ radioimmunotherapy with ${ }^{212} \mathrm{~Pb}-\mathrm{TCMC}$-trastuzumab [abstract]. J Nucl Med. 2015;56(suppl):90P.

70. Nagy P, Friedlander E, Tanner M, et al. Decreased accessibility and lack of activation of ErbB2 in JIMT-1, a Herceptin-resistant, MUC4-expressing breast cancer cell line. Cancer Res. 2005;65:473-482.

71. Tolmachev V, Wallberg H, Sandstrom M, Hansson M, Wennborg A, Orlova A. Optimal specific radioactivity of anti-HER2 Affibody molecules enables discrimination between xenografts with high and low HER2 expression levels. Eur $J$ Nucl Med Mol Imaging. 2011;38:531-539. 